\title{
Strain-Specific Resistance to Potato virus Y (PVY) in Potato and Its Effect on the Relative Abundance of PVY Strains in Commercial Potato Fields
}

Cassandra N. Funke, Department of Plant, Soil and Entomological Sciences (PSES), University of Idaho, Moscow; and Department of Botany \& Plant Pathology, Hermiston Agricultural Research and Extension Center, Oregon State University, Hermiston; Olga V. Nikolaeva, Kelsie J. Green, Lisa T. Tran, Mohamad Chikh-Ali, and Arturo Quintero-Ferrer, Department of PSES, University of Idaho, Moscow; Robert A. Cating, Kenneth E. Frost, and Philip B. Hamm, Department of Botany \& Plant Pathology, Hermiston Agricultural Research and Extension Center; Nora Olsen, Department of PSES, University of Idaho, Kimberly; Mark J. Pavek, Department of Horticulture, Washington State University, Pullman; Stewart M. Gray, United States Department of Agriculture-Agricultural Research Service (USDA-ARS), Section of Plant Pathology and Plant-Microbe Biology, Cornell University, Ithaca, NY; James M. Crosslin, Department of PSES, University of Idaho, Moscow; and USDA-ARS, Prosser, WA; and Alexander V. Karasev, Department of PSES, University of Idaho, Moscow

\begin{abstract}
Potato virus $Y$ (PVY) is a serious threat to potato production due to effects on tuber yield and quality, in particular, due to induction of potato tuber necrotic ringspot disease (PTNRD), typically associated with recombinant strains of PVY. These recombinant strains have been spreading in the United States for the past several years, although the reasons for this continuing spread remained unclear. To document and assess this spread between 2011 and 2015, strain composition of PVY isolates circulating in the Columbia Basin potato production area was determined from hundreds of seed lots of various cultivars. The proportion of nonrecombinant $\mathrm{PVY} \mathrm{O}^{\mathrm{O}}$ isolates circulating in Columbia Basin potato dropped ninefold during this period, from $63 \%$ of all PVY-positive plants in 2011 to less than 7\% in 2015. This drop in $\mathrm{PVY}^{\mathrm{O}}$ was concomitant with the rise of the recombinant $\mathrm{PVY}^{\mathrm{N}-\mathrm{Wi}}$ strain incidence, from less than $27 \%$ of all PVY-positive plants in

2011 to $53 \%$ in 2015 . The proportion of the PVY ${ }^{\mathrm{NTN}}$ recombinant strain, associated with PTNRD symptoms in susceptible cultivars, increased from $7 \%$ in 2011 to approximately $24 \%$ in 2015 . To further address the shift in strain abundance, screenhouse experiments were conducted and revealed that three of the four most popular potato cultivars grown in the Columbia Basin exhibited strain-specific resistance against $\mathrm{PVY} \mathrm{Y}^{\mathrm{O}}$. Reduced levels of systemic movement of $\mathrm{PVY} \mathrm{Y}^{\mathrm{O}}$ in such cultivars would favor spread of recombinant strains in the field. The negative selection against the nonrecombinant $\mathrm{PVY}^{\mathrm{O}}$ strain is likely caused by the presence of the $N y_{t b r}$ gene identified in potato cultivars in laboratory experiments. Presence of strain-specific resistance genes in potato cultivars may represent the driving force changing PVY strain composition to predominantly recombinant strains in potato production areas.
\end{abstract}

In the past 15 to 20 years, Potato virus $Y$ (PVY) has been a major problem for potato in the United States (Gray et al. 2010; Karasev and Gray 2013) due to the gradual spread of recombinant strains often associated with the potato tuber necrotic ringspot disease (PTNRD) (Crosslin et al. 2002, 2006; Gray et al. 2010; Karasev et al. 2008; Lorenzen et al. 2006a, 2008; Piche et al. 2004). PVY exists as a complex of at least nine strains that differ in host specificity in various solanaceous species, and cause a range of symptoms in different potato cultivars (Karasev and Gray 2013; Singh et al. 2008). PVY affects both potato yield and tuber quality, resulting in substantial economic losses for both seed potato producers and ware potato producers supplying the fresh and processed market (Beczner et al. 1984; Benedict et al. 2015; Hane and Hamm 1999; Le Romancer et al. 1994; Nolte et al. 2004).

Originally, strains of PVY were classified based on the induction of hypersensitive resistance (HR) response in a standard set of potato (Solanum tuberosum) cultivars with known genetic backgrounds (Cockerham 1970; de Bokx and Huttinga 1981; Jones 1990; Singh et al. 2008). The HR response in $S$. tuberosum was triggered due to the presence of three strain-specific $N$ resistance genes $(N y, N c$, and $N z$ ), and four strains were genetically defined: $\mathrm{PVY}^{\mathrm{O}}$ (triggering $\left.N y_{t b r}\right), \mathrm{PVY}^{\mathrm{C}}$ (triggering $N c_{t b r}$ ), $\mathrm{PVY}^{\mathrm{Z}}$ (triggering $N z_{t b r}$ ), and $\mathrm{PVY}^{\mathrm{N}}$ (overcoming all three $N$ genes without the HR response) (Chikh-Ali et al. 2014; Cockerham 1970; Jones 1990; Singh et al. 2008). Molecular characterization of $\mathrm{PVY}$ strains revealed that $\mathrm{PVY}^{\mathrm{O}}, \mathrm{PVY}^{\mathrm{N}}$, and $\mathrm{PVY}^{\mathrm{C}}$ had nonrecombinant genomes that formed three separate

Corresponding author: A. V. Karasev; E-mail akarasev@uidaho.edu

Accepted for publication 13 August 2016.

C) 2017 The American Phytopathological Society phylogenetic clades (Glais et al. 2002; Karasev and Gray 2013; Lorenzen et al. 2006a; Singh et al. 2008). PVYZ, on the other hand, was found to have a recombinant genome built of $P V Y^{\mathrm{O}}$ and $\mathrm{PVY}^{\mathrm{N}}$ parental sequences that was classified as either PVY $\mathrm{Y}^{\mathrm{NTN}}$ or PVY ${ }^{\text {NTN-NW }}$ recombinant based on molecular characteristics (Chikh-Ali et al. 2010, 2014; Hu et al. 2009a; Karasev and Gray 2013; Kerlan et al. 2011). Recently, $\mathrm{PVY}^{\mathrm{Z}}$ was proposed to include other, nonrecombinant isolates as well (Jones and Kehoe 2016; Kehoe and Jones 2016). There are multiple other recombinants, most often built of $\mathrm{PVY} \mathrm{O}^{\mathrm{O}}$ and $\mathrm{PVY}^{\mathrm{N}}$ parental sequences, named PVY ${ }^{\mathrm{N}-\mathrm{Wi}}, \mathrm{PVY}^{\mathrm{N}: \mathrm{O}}, \mathrm{PVY}-\mathrm{NE} 11$, and others (Karasev and Gray 2013), but these were not defined genetically and were classified only based on molecular properties.

Epidemiological data on PVY strain prevalence in potato is available for different production areas and sometimes over multiple years (Anfoka et al. 2014; Baldauf et al. 2006; Chikh-Ali et al. 2010, 2016a,b; Crosslin et al. 2006; Djilani-Khouadja et al. 2010; Ellis et al. 1997; Galvino-Costa et al. 2012a; Gray et al. 2010; Karasev et al. 2008; Kerlan et al. 1999; Lorenzen et al. 2006a, 2008; Schubert et al. 2007, 2015). In Western Europe (Kerlan et al. 1999; Schubert et al. 2007), Brazil (Galvino-Costa et al. 2012a), the Mediterranean (Djilani-Khouadja et al. 2010), the Middle East (Anfoka et al. 2014; Chikh-Ali et al. 2010, 2016a), and Indonesia (Chikh-Ali et al. 2016b), there was a consistent trend over the past 30 years in which recombinant strains such as $\mathrm{PVY}^{\mathrm{NTN}}$ and $\mathrm{PVY}^{\mathrm{N}-\mathrm{Wi}}$ replaced nonrecombinant $\mathrm{PVY}^{\mathrm{C}}, \mathrm{PVY}^{\mathrm{O}}$, and $\mathrm{PVY}^{\mathrm{N}}$ isolates as the most common in potato production. Until recently, one of the few remaining strongholds for $\mathrm{PVY}^{\mathrm{O}}$ was the United States, where it was the most abundant strain found in the 2004-to-2006 PVY strain survey (Gray et al. 2010). However, recombinant strains were identified in the United States as well (Baldauf et al. 2006; Crosslin et al. 2002, 2006; Gray et al. 2010; Karasev et al. 2008; Lorenzen et al. 2006a, 2008), and there was a general concern that recombinant strains may continue to spread as they had in other countries (Gray et al. 2010). 
Various explanations were suggested for this observed transition from nonrecombinant to recombinant strains of PVY, including marketing of new susceptible potato cultivars, more efficient transmission by aphids, more efficient translocation into tubers, strainspecific resistance, influx of new, exotic isolates of PVY, and others (Karasev and Gray 2013). Experimental evidence for any of these factors being involved in the observed shift to the recombinant strains of PVY in potato production was limited and not convincing. The problem was due partly to the shortage of studies on the (strainspecific) HR induction in U.S. potato cultivars and partly to the lack of consistent epidemiological surveys addressing PVY strain composition in an area representing a substantial segment of the potato production in the United States. Nevertheless, PVY isolates from strains $\mathrm{PVY}^{\mathrm{O}}$ and $\mathrm{PVY}^{\mathrm{Z}}$ were studied for their ability to elicit HR in several potato cultivars harboring $N y_{t b r}$ and $N z_{t b r}$ genes, respectively, and grown in the United States (Chikh-Ali et al. 2014; Karasev et al. 2011; Kehoe and Jones 2016; Kerlan et al. 2011; Rowley et al. 2015). The virus determinant involved in interaction with the $N y_{t b r}$ gene in potato and, hence, in triggering the HR response was mapped within the HC-Pro cistron of the PVY genome (Tian and Valkonen 2013, 2015). The HR response was found to provide partial resistance against $\mathrm{PVY} \mathrm{Y}^{\mathrm{O}}$ and $\mathrm{PVY} \mathrm{Z}^{\mathrm{S}}$ strains of PVY (Jones 1990; Kerlan et al. 2011; Rowley et al. 2015), restricting virus strains mostly to cultivars in which they did not evoke hypersensitivity (Cockerham 1970; Jones 1990; Karasev and Gray 2013).

Potato production in the Columbia Basin takes place in seven counties of the south-central state of Washington and in two counties of the north-central state of Oregon, along the Columbia River. This area is responsible for almost $30 \%$ of U.S. potato production (NASS 2015). Here, we present data for the field survey of PVY strains circulating in the Columbia Basin potato production area between 2011 and 2015, reflecting the dynamic nature of the PVY strain composition there. These data may be viewed as a good estimation of the
PVY strain composition changes in the entire United States, particularly because the hundreds of seed lots tested were also shipped and used throughout North America. We also conducted a controlled study of the PVY strain changes in four potato cultivars widely grown in the Columbia Basin and observed a similar strain composition shift apparent within a single growing season. This shift in the proportion of PVY strains circulating in potato was directly linked to the strain-specific HR response associated with the presence of $N$ genes in three of the four studied cultivars: 'Alturas', 'Umatilla Russet', and 'Ranger Russet'.

\section{Materials and Methods}

Field plot design and locations. The Washington seed lot trials were planted at the Washington State University research farm near Othello and the Oregon seed lot trials were planted at the Hermiston Agricultural Research and Extension Center, Oregon State University, Hermiston. These trials were conducted from 2011 to 2015 using certified seed lots imported into Washington and Oregon from a number of U.S. states and Canadian provinces (Pavek and Holden 2016). Whole tubers were submitted by the growers in the Columbia Basin and planted in Oregon and Washington in single rows at 200 tubers/seed lot. Plant spacing was $25 \mathrm{~cm}$ and rows were $85 \mathrm{~cm}$ apart. Fertilization, irrigation frequency, and insect, weed, and disease control practices were consistent with commercial potato production practices in the Columbia Basin. Planting dates varied each year, depending on receipt of seed lots, but ranged from late April to late May. The designs of the field plots and locations were the same as described previously (Crosslin et al. 2006).

Plant sampling, PVY testing, and serotyping. Each year in early to mid-June, seed lot trials were visually assessed by a group of Pacific Northwest (Washington, Oregon, Idaho, and Montana) potato pathologists, extension specialists, and volunteers for abiotic and
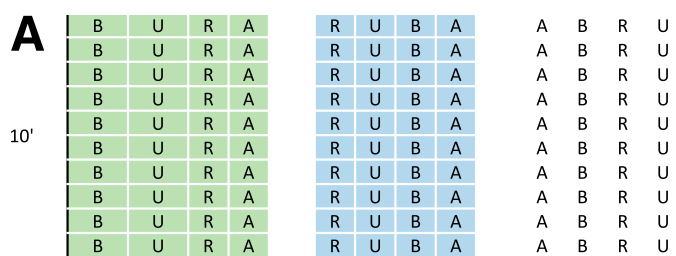

$10^{\prime} \quad$\begin{tabular}{|llll}
$U$ & $A$ & $R$ & $B$ \\
$U$ & $A$ & $R$ & $B$ \\
$U$ & $A$ & $R$ & $B$ \\
$U$ & $A$ & $R$ & $B$ \\
$U$ & $A$ & $R$ & $B$ \\
$U$ & $A$ & $R$ & $B$ \\
$U$ & $A$ & $R$ & $B$ \\
$U$ & $A$ & $R$ & $B$ \\
$U$ & $A$ & $R$ & $B$ \\
$U$ & $A$ & $R$ & $B$
\end{tabular}

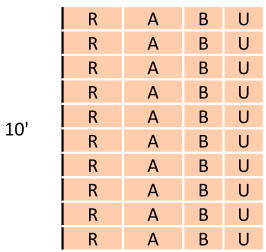

B $\quad R \quad U \quad A$

B $R \quad$ R $A$

B $R \quad U \quad A$

B $R \quad U \quad A$

B $R \quad U \quad A$

$B \quad R \quad A$

$\begin{array}{llll}B & R & U & A \\ B & R & U & A\end{array}$

$\begin{array}{llll}B & R & U & A \\ B & R & U & A\end{array}$

$10 \quad \begin{array}{llll}R & A & B & U \\ R & A & B & U \\ R & A & B & U \\ R & A & B & U \\ R & A & B & U \\ R & A & B & U \\ R & A & B & U \\ R & A & B & U \\ R & A & B & U \\ R & A & B & U\end{array}$

Row \begin{tabular}{l|l|l|l|}
$R$ & $U$ & $B$ & $A$ \\
$R$ & $U$ & $B$ & $A$
\end{tabular}

\begin{tabular}{|l|l|l|l|}
\hline$R$ & $U$ & $B$ & $A$ \\
\hline$R$ & $U$ & $B$ & $A$
\end{tabular}

\begin{tabular}{l|l|l|l|l}
$R$ & $U$ & $B$ & $A$
\end{tabular}

\begin{tabular}{l|l|l|l|l|l|l|l|l|l|l}
$R$ & $U$ & $B$ & $A$ \\
\hline & $U$ & B & A
\end{tabular}

\begin{tabular}{l|l|l|l|}
$R$ & U & B & A \\
\hline R & U & B & A \\
\hline
\end{tabular}

\begin{tabular}{l|l|l|l|l}
$R$ & $U$ & $B$ & $A$ \\
\hline & A & B & A \\
\hline
\end{tabular}

\begin{tabular}{l|l|l|l|l}
$R$ & $U$ & $B$ & $A$ \\
$R$ & $U$ & $B$ & $A$
\end{tabular}

\begin{tabular}{l|l|l|l|l}
$R$ & $U$ & $B$ & $A$
\end{tabular}

\begin{tabular}{l|l|l|l}
$R$ & $U$ & $B$ & $A$ \\
\hline
\end{tabular}

\begin{tabular}{l|l|l|l|}
\hline$R$ & U & B & A
\end{tabular}

$\begin{array}{llll}5 & 6 & 7 & 8\end{array}$

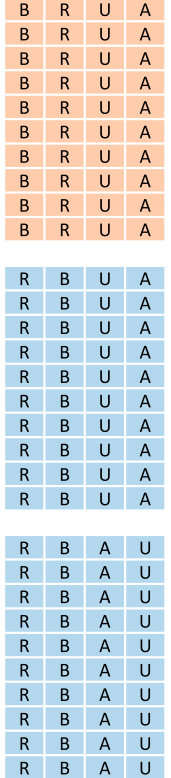

B

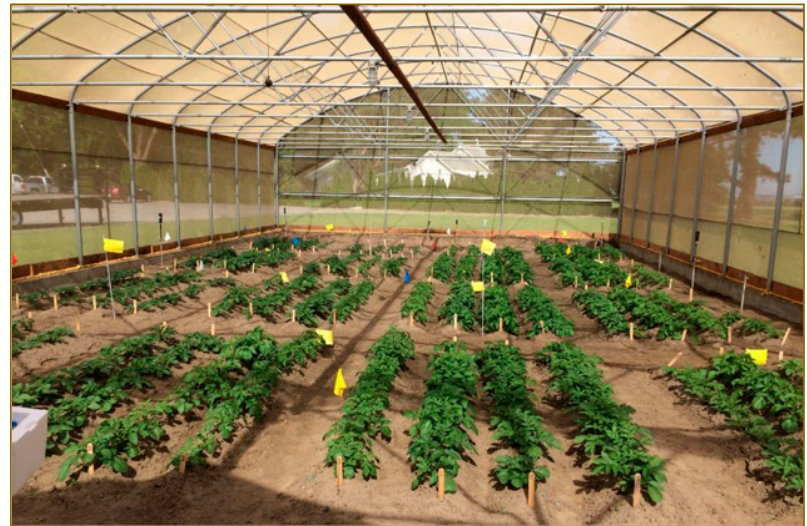

May 27, 2015

Fig. 1. A, Screenhouse experiment layout, showing the dimensions of the plot and randomized block design of the experiment. Letters indicate individual potato plants: $B=$ Russet Burbank, $U=$ Umatilla Russet, $R=$ Ranger Russet, and $A=$ Alturas. Shading color designates the Potato virus $Y$ (PVY) strain used for inoculation: green means PVYO (isolate Tb60), blue means $P V Y^{N-W i}$ (isolate N1), orange means PVYNTN (isolate HR1), and no shading means uninoculated. B, Picture of the screenhouse plot just prior to inoculation with $\mathrm{PVY}$ isolates. 
biotic abnormalities, and each plant displaying an abnormality was flagged. Specifically, each plant showing mosaic symptoms attributed to virus infection was marked with a yellow flag. Sample collection for the PVY testing and typing was conducted on the day of the first reading and flagging, not more than $2 \mathrm{~h}$ after this reading was completed. Samples were collected from each seed lot having at least one yellow flag but not more than 10 samples per lot, due to limited testing and typing resources. The number of samples collected varied between 222 and 431 for Othello, WA and between 101 and 215 for Hermiston, OR, and depended on the number of seed lot samples submitted for the testing each year and the relative incidence of infection for any given season. Three leaves per flagged plant were collected and placed in a sealable plastic bag labeled with the seed lot number. Bags were kept in coolers on ice or in a cold room at approximately $4^{\circ} \mathrm{C}$ until processing for PVY strain typing, usually within 2 to 3 days after collection.

In the 2011 to 2015 seasons, all Othello samples were initially tested by triple-antibody sandwich enzyme-linked immunosorbent assay (TAS-ELISA), as described previously (Karasev et al. 2010; Nikolaeva et al. 2012), with some modifications. Four monoclonal antibodies were routinely used in this assay to determine the serotype of the PVY strain present: Asc5, 1F5, SASA-N, and MAb2 (occasionally, SASA-O was used in place of Mab2). Asc5 is a strain-nonspecific mouse monoclonal antibody cocktail, produced against purified PVY isolate Mont $\left(\mathrm{PVY}^{\mathrm{N}}\right)$ through a series of intramuscular injections into a mouse, with subsequent fusion of spleen and myeloma cells, selection of hybridoma cell lines producing PVY-specific immunoglobulins, and production of ascites in mice (O. V. Nikolaeva and A. V. Karasev, unpublished). Monoclonal antibodies 1F5 (Ellis et al. 1996) and MAb2 (McDonald and Kristjansson 1993) were obtained from Agdia (Elkhart, IN) or from Phyto Diagnostics (North Saanich, BC, Canada). 1F5 is specific to $\mathrm{PVY}^{\mathrm{N}}, \mathrm{PVY}^{\mathrm{NTN}}$, and PVY ${ }^{\mathrm{O} 5}$, and MAb2 is specific to the PVY $\mathrm{P}^{\mathrm{O}}$, $\mathrm{PVY}^{\mathrm{N}-\mathrm{Wi}}$, and $\mathrm{PVY}^{\mathrm{C}}$ strains. Monoclonal antibodies SASA-N and SASA-O were obtained from the Scottish Agricultural Science Agency (SASA, Edinburgh). SASA-N is specific to $\mathrm{PVY}^{\mathrm{N}}$ and $\mathrm{PVY}^{\mathrm{NTN}}$, and SASA-O is specific to the PVY $\mathrm{PVY}^{\mathrm{O}-\mathrm{Wi}}$, and $\mathrm{PVY}^{\mathrm{C}}$ strains.

Reverse-transcription polymerase chain reaction-based PVY strain typing. In the 2011 to 2015 seasons in the Hermiston, OR trials, PVY strain typing was conducted using the reversetranscription polymerase chain reaction (RT-PCR) methodology developed by Lorenzen et al. (2006b). The same method was also used in the 2011 season on samples originated from the Othello, WA trials. In both cases, samples identified by TAS-ELISA as positive were subjected to a separate total nucleic acid extraction, and then used in RT-PCR assays according to Lorenzen et al. (2006b). With this methodology, nonrecombinant $\mathrm{PVY}^{\mathrm{O}}$ and $\mathrm{PVY}^{\mathrm{N}}$ strains can be distinguished from recombinant $\mathrm{PVY}^{\mathrm{NTN}}$ and $\mathrm{PVY} \mathrm{Y}^{\mathrm{N}-\mathrm{Wi} / \mathrm{N}: \mathrm{O}}$ strains; however, no distinction can be made between $\mathrm{PVY} \mathrm{Y}^{\mathrm{N}: \mathrm{O}}$ and $\mathrm{PVY} \mathrm{Y}^{\mathrm{N}-\mathrm{Wi}}$ strains, and no distinction is possible between PVYNA-N and PVY-NE11 strains (Chikh-Ali et al. 2013a; Lorenzen et al. 2006b). In 2012, PVY-positive samples from Othello trials were subjected to an additional RT-PCR typing according to an improved methodology (Chikh-Ali et al. 2010), with the same total nucleic acid extracts used for the Lorenzen et al. (2006b) method as well. In 2013 to 2015, the samples from Othello were typed using the immunocapture (IC) RT-PCR methodology developed recently (Chikh-Ali et al. 2013a). In this method, the extraction of the sample was the same as for ELISA tests, the samples were loaded onto the IC plates at the same time as ELISA samples, and RT-PCR typing was conducted using both Lorenzen et al. (2006b) and Chikh-Ali et al. (2010) protocols. In this combined typing, more than nine strains of PVY can be distinguished, including nonrecombinant $\mathrm{PVY} \mathrm{Y}^{\mathrm{O}}, \mathrm{PVY}^{\mathrm{N}}$, and PVYNA-N and recombinant $\mathrm{PVY}^{\mathrm{NTN}}, \mathrm{PVY}^{\mathrm{N}-\mathrm{Wi}}, \mathrm{PVY}^{\mathrm{N}: \mathrm{O}}$, and PVY-NE11 (Chikh-Ali et al. 2013a).

Layout of the 2015 screenhouse experiment. In spring to summer 2015, a screenhouse experiment was conducted at Hermiston, OR to assess the infection rate of three strains of PVY in the four most common potato varieties grown in the Columbia Basin. The screenhouse was used to both mimic the field conditions for potato production and minimize any current-season spread of the virus by excluding aphids, by thorough insecticide application, and by the use of mechanical inoculation. In all, 160 plants each of 'Russet Burbank', 'Alturas', 'Umatilla Russet', and 'Ranger Russet' were divided into four groups: infected with $\mathrm{PVY}^{\mathrm{O}}$ (isolate Tb60), $\mathrm{PVY}^{\mathrm{N}-\mathrm{Wi}}(\mathrm{N} 1)$, or PVY ${ }^{\text {NTN }}$ (HR1), or left uninfected. On 16 April 2015, nuclear seed minitubers of the four potato varieties, the most widely planted cultivars used in the Columbia Basin, were planted into a 22-by-11-meter screenhouse in a randomized complete block design in Hermiston (Fig. 1). The experiment had 16 treatments: four varieties $\times$ three strains of PVY plus one untreated check $($ UTC $) \times 10$ plants $\times$ four replications $=$ 640 plants. Hence, each of the four potato varieties was represented by 160 plants, with 40 plants inoculated with each of the three PVY strains plus 40 plants of UTC. Prior to inoculation, all plants were sampled and tested for possible PVY presence. Leaves from each plant in each row were sampled, bulked (10 plants/group), and assayed for PVY using RT-PCR (Cating et al. 2015). No PVY-positive plants were detected prior to inoculation. Potato plants were then mechanically inoculated with the PVYO (isolate Tb60), PVY ${ }^{N T N}(\mathrm{HR} 1)$, and PVY ${ }^{\mathrm{N}-\mathrm{Wi}}(\mathrm{N} 1)$ strains of PVY on 27 May 2015, when plants were approximately 20 to $76 \mathrm{~cm}$ in height (Fig. 1). Each virus strain was inoculated one at a time to avoid potential contamination. After inoculation, each plant was rinsed with water to remove excess inoculum from the leaves. Five weeks later (on 1 July 2015), individual plants were sampled; upper, uninoculated leaves were assayed for PVY; and PVY-positive samples were typed to strain using ELISA and RT-PCR according to the previously published methodology (Chikh-Ali et al. 2013a; Nikolaeva et al. 2012).

Potato cultivar sources and plant maintenance. 'Maris Bard' potato was originally received from the National Potato Germplasm Collection in Sturgeon Bay, WI as tissue culture plantlets. Three other cultivars ('Desiree', 'CalWhite', and 'Umatilla Russet') were obtained from the University of Idaho Potato Tissue Culture Laboratory (provided by Lorie Ewing). Plantlets were cut and transferred to new media every 8 weeks and, after transfer, these plantlets were planted in soil in 2 to 8 weeks. While in vitro, the plantlets were periodically subjected to RT-PCR tests for main potato viruses to confirm their virus-free status.

Reference isolates of PVY, inoculations, phenotype screening, and laboratory testing. All isolates of PVY used in this work were from the laboratory collection at the University of Idaho and have been previously subjected to whole-genome sequencing (Table 1). PVY isolates were maintained in 'Burley' tobacco in an insect-free, climate-controlled growth chamber. Infected tobacco tissue was used as an inoculum, homogenized in phosphate buffer $(50 \mathrm{mM}$ sodium phosphate [pH 7.0] plus $50 \mathrm{mM} \mathrm{Na}$ DIECA) at a dilution rate of 1:10 (wt/vol) with a mortar and pestle on ice. For all cultivars, potato plants were mechanically inoculated at the 6- to 10-leaf stage and grown in growth chambers with a cycle of $16 \mathrm{~h}$ of light and $8 \mathrm{~h}$ of darkness and maintained at 20 to $22^{\circ} \mathrm{C}$. Mechanical inoculations and symptom assessment were conducted as described previously (Rowley et al. 2015). Three plants of each cultivar were inoculated with each PVY isolate per experiment. The symptom assessment started 4 to 5 days after inoculation and was carried out for 6 to 8 weeks, focusing on two types of symptoms: (i) local and systemic necrotic reactions which indicated the induction of the HR and typically revealed the presence of a corresponding $N$ gene in a cultivar and (ii) presence or absence of other systemic symptoms not associated with HR. Each experiment was repeated three times.

\section{Results}

Changes in PVY strain composition in Columbia Basin potato fields between 2011 and 2015. The number of mosaic samples analyzed for the presence of PVY varied during the five seasons of testing, from 222 to 431 per season in Othello seed lot trials and from 101 to 215 in Hermiston seed lot trials (Table 2). In the span of five seasons, over 1,400 mosaic samples were tested and typed in Othello 
trials and over 800 samples were analyzed in Hermiston trials. PVY-positive samples represented 84 to $93 \%$ of all collected samples exhibiting mosaic in Othello and 82 to $93 \%$ of samples collected in Hermiston (Table 2). The 7 to $18 \%$ of mosaic samples testing negative for PVY may represent a margin of error characteristic of visual symptom reading or infections by other viruses; however, PVY was responsible for the majority of the mosaic symptoms identified in potato planted in the Columbia Basin between 2011 and 2015. Typing these PVY-positive samples to strain revealed dynamic changes to the composition of PVY strains present in this potato production area. Specifically, $\mathrm{PVY}^{\mathrm{O}}$ prevalence decreased ninefold in the Othello trials, from 63 to less than 7\% (Table 3), whereas, in Hermiston, this drop was less but still pronounced, from 47 to $9 \%$ (Table 4). This less dramatic drop in Hermiston trials could be due, in part, to a large proportion of unclassified samples in 2011 at this location. In both locations, the drop in the relative abundance of the $\mathrm{PVY}{ }^{\mathrm{O}}$ strain was accompanied by a concomitant rise in the proportion of recombinant strains (in particular, $\mathrm{PVY}^{\mathrm{N}-\mathrm{Wi}}$ ) which, in the Othello trials, almost doubled from under 27 to $53 \%$ of all PVY-positive plants between 2011 and 2015 (Table 3). Similar trends were observed in Hermiston, where the relative abundance of recombinant PVY strains $\mathrm{PVY}^{\mathrm{N}: \mathrm{O}}$ and $\mathrm{PVY}^{\mathrm{N}-\mathrm{Wi}}$ together increased from 8 to $59 \%$ from 2011 to 2015 (Table 4). During the same period, the relative abundance of PVY ${ }^{\mathrm{NTN}}$ increased more than threefold (from less than 8 to more than 24\%) in the Othello trials (Table 3) and increased twofold (from 12 to $24 \%$ ) at the Hermiston location. In the Othello trials, the share of another recombinant strain, PVY-NE11, rose from 2011 to 2013 more than 10-fold (from less than 1 to 10\%) but then dropped again to less than $1 \%$ in 2015 (Table 3). The proportion of the PVY ${ }^{\mathrm{N}: O}$ strain fluctuated between 2 and 3\% between 2012 and 2014 but, in 2015, rose to more than $9 \%$ (Table 3). Two nonrecombinant strains, $\mathrm{PVY}^{\mathrm{N}}$ and PVYO-O5, were found only in 2011 and 2012 (Table 3). The overall strain composition of PVY isolates circulating in the Columbia Basin potato changed drastically during the observation period, from the predominantly nonrecombinant $\mathrm{PVY}^{\mathrm{O}}$ strain $(63 \%)$ in 2011 to predominantly recombinant strains represented by $\mathrm{PVY}^{\mathrm{N}-\mathrm{Wi}}(53 \%), \mathrm{PVY}^{\mathrm{NTN}}$ $(24 \%), \mathrm{PVY}^{\mathrm{N}: \mathrm{O}}(9 \%)$, and PVY-NE11 $(0.5 \%)$ (Table 3). The two recombinant strains associated with PTNRD, PVY ${ }^{\mathrm{NTN}}$ and PVYNE11, combined, represented $8.7 \%$ of all PVY-positive plants in 2011 and increased to $24.6 \%$, nearly threefold, in 2015 (Table 3). Large changes in the proportion of $\mathrm{PVY}^{\mathrm{N}: \mathrm{O}}$ strain also occurred, although its relative abundance never reached $10 \%$ of all PVY-positive plants detected during the period of observations.

Strain-specific resistance in potato cultivars may be driving the changes in PVY strain composition. Visual assessment of the virus infection in different strain-cultivar combinations in the screenhouse experiment indicated that $\mathrm{PVY} \mathrm{O}^{\mathrm{O}}$ infection was often associated with systemic necrotic symptoms typical of HR in Alturas, Umatilla Russet, and Ranger Russet. These consisted of multiple green rings, necrotic lesions, and vein necrosis on infected leaves (Fig. 2A and B) and, for Ranger Russet, of necrotic leaf-drop and necrotic stem streaks (Fig. 2C). Similar systemic HR reactions against the $\mathrm{PVY}^{\mathrm{O}}$ strain have been reported previously for Alturas and Ranger Russet (Rowley et al. 2015) infected under greenhouse conditions. However, the response of Umatilla Russet against different PVY strains has not previously been studied.

In the screenhouse, Russet Burbank did not display any reduction in systemic movement of the three PVY strains used as a challenge, with infection incidence varying from $70 \%$ for $\mathrm{PVY}^{\mathrm{NTN}}$ to $78 \%$ for

Table 2. Proportion of Potato virus $Y$ (PVY)-positive samples collected exhibiting mosaic symptoms at two commercial seed lot trial locations, 2011 to $2015^{\mathrm{a}}$

\begin{tabular}{lccccc}
\hline & \multicolumn{2}{c}{ Othello, WA } & & \multicolumn{2}{c}{ Hermiston, OR } \\
\cline { 2 - 3 } Season & $\boldsymbol{N}$ & PVY+ (\%) & & $\boldsymbol{N}$ & PVY+ (\%) \\
\hline 2011 & 246 & 87.7 & & 101 & 82 \\
2012 & 235 & 84.3 & & 206 & 86 \\
2013 & 283 & 88.0 & & 114 & 89 \\
2014 & 222 & 90.5 & & 215 & 93 \\
2015 & 431 & 92.6 & & 192 & 88 \\
\hline
\end{tabular}

${ }^{a} N=$ number of mosaic samples tested and PVY $+=$ PVY-positive samples.

Table 3. Potato virus $Y(\mathrm{PVY})$ strain breakdown at Othello, WA, seed lot trials, 2011 to 2015

\begin{tabular}{lrrrrrrrrrc}
\hline & \multicolumn{1}{c}{ PVY strain type, percentage of all PVY-positive plants } \\
\cline { 2 - 10 } Season & O & N-Wi & N:O & NTN & NE-11 & NA-N & N & O5 & Uncl. $^{\mathbf{a}}$ \\
\hline $2011^{\mathrm{b}}$ & 62.6 & 27.4 & 7.8 & 0.9 & & 0 & 0.5 & 0.9 \\
2012 & 30.8 & 37.4 & 3.0 & 13.1 & 5.6 & 0 & 5.6 & 1.0 & 3.5 \\
2013 & 17.3 & 46.6 & 2.4 & 20.5 & 10.0 & 0 & 0 & 0 & 3.2 \\
2014 & 15.9 & 59.2 & 2.0 & 6.0 & 8.0 & 0 & 0 & 0 & 9.0 \\
2015 & 6.8 & 52.9 & 9.3 & 24.1 & 0.5 & 0 & 0 & 0 & 6.6 \\
\hline
\end{tabular}

${ }^{a}$ Unclassified or inconclusive.

${ }^{\mathrm{b}}$ In 2011, samples from Othello were typed to strain by the methodology of Lorenzen et al. (2006b) only and, consequently, no distinction could be made between N-Wi and N:O strains or between NE-11 and NA-N strains.

Table 4. Potato virus $Y$ (PVY) strain breakdown at Hermiston, OR, seed lot trials, 2011 to $2015^{\mathrm{a}}$

\begin{tabular}{lccccccc}
\hline & \multicolumn{7}{c}{ PVY strain type, percentage of all PVY-positive plants } \\
\cline { 2 - 8 } Season & O & N-Wi, N:O & NTN & NE-11, NA-N & N & O5 & Uncl. $^{\mathbf{b}}$ \\
\hline 2011 & 47 & 8 & 12 & 0 & 0 & 0 & 33 \\
2012 & 39 & 50 & 11 & 0 & 0 & 0 & 0 \\
2013 & 26 & 53 & 14 & 0 & 0 & 0 & 7 \\
2014 & 35 & 45 & 17 & 0 & 0 & 0 & 3 \\
2015 & 9 & 59 & 24 & 0 & 0 & 0 & 5 \\
\hline
\end{tabular}

${ }^{a}$ Samples were typed to strain by the methodology of Lorenzen et al. (2006b) only and, consequently, no distinction could be made between $\mathrm{N}-\mathrm{Wi}$ and $\mathrm{N}$ : $\mathrm{O}$ strains or between NE-11 and NA-N strains.

${ }^{\mathrm{b}}$ Unclassified or inconclusive.

Table 1. Genotypes and phenotypic traits of the Potato virus $Y$ (PVY) isolates used in this study

\begin{tabular}{|c|c|c|c|c|c|}
\hline Isolates & Strain $^{\mathbf{a}}$ & Genotype & Bioassay $^{\mathbf{b}}$ & Serotype & Genome sequence $^{c}$ \\
\hline Tb60 & $\mathrm{PVYO}$ & $\mathrm{PVYO}^{\mathrm{O}}$ & Mos & $\mathrm{O}$ & O-type sequence EF026074 \\
\hline ID269 & $\mathrm{PVY}^{\mathrm{O}}$ & PVYO-O5 & Mos & O5 & O5-type sequence FJ643477 \\
\hline N1 & PVYN-Wi & PVYN-Wi & $\mathrm{VN}$ & $\mathrm{O}$ & Recombinant HQ912863 \\
\hline Alt & PVYN:O & $\mathrm{PVY}^{\mathrm{N}: \mathrm{O}}$ & $\mathrm{VN}$ & $\mathrm{O}$ & Recombinant AY884985 \\
\hline Mont & $\mathrm{PVYN}^{\mathrm{N}}$ & $\mathrm{PVY}^{\mathrm{N}}$ & $\mathrm{VN}$ & $\mathrm{N}$ & N-type sequence AY884983 \\
\hline HR1 & $\mathrm{PVYZ}^{\mathrm{Z}}$ & PVYNTN $\left(\mathrm{PVY}^{\mathrm{Z}}{ }_{-\mathrm{NTN}}\right)$ & $\mathrm{VN}$ & $\mathrm{N}$ & Recombinant FJ204166 \\
\hline L26 & $\mathrm{PVY}^{\mathrm{Z}}$ & $\mathrm{PVY}^{\mathrm{NTN}}\left(\mathrm{PVY}^{\mathrm{Z}}-\mathrm{NTN}\right)$ & Mos & $\mathrm{N}$ & Recombinant FJ204165 \\
\hline RRA-1 & PVYNA-N & PVYNA-N & VN & $\mathrm{N}$ & NA-N-type sequence AY884984 \\
\hline ID20 & NE-11 & NE-11 & $\mathrm{VN}$ & $\mathrm{N}$ & Recombinant HQ912867 \\
\hline
\end{tabular}

\footnotetext{
a Strains listed according to Karasev and Gray (2013).

${ }^{\mathrm{b}}$ Tobacco symptoms: $\mathrm{VN}=$ vein necrosis and $\mathrm{Mos}=$ mosaic and vein clearing.

${ }^{c}$ Sequences deposited in GenBank.
} 
PVYN-Wi (Fig. 3). The three other cultivars exhibited reduced systemic movement for $\mathrm{PVY} \mathrm{Y}^{\mathrm{O}}$, with $\mathrm{PVY} \mathrm{Y}^{\mathrm{O}}$ infection incidence ranging from $55 \%$ for Alturas to $40 \%$ for Umatilla Russet and less than $28 \%$ for Ranger Russet (Fig. 3). Under these same screenhouse conditions, infection incidence of $\mathrm{PVY}^{\mathrm{N}-\mathrm{Wi}}$ was significantly higher in these three cultivars than in Russet Burbank: 85\% in Ranger Russet, $90 \%$ in Umatilla Russet, and $92 \%$ in Alturas. Infection incidences for $\mathrm{PVY}^{\mathrm{NTN}}$ were also significantly higher in all of the three cultivars relative to Russet Burbank (Fig. 3).

Examination of the number of plants infected systemically in each cultivar-strain combination provided evidence that the strain- specific resistance exhibited by Alturas, Umatilla Russet, and Ranger Russet in the screenhouse resulted in a significant difference in strain prevalence between the expected infection from the inoculation and observed infection at the end of the experiment (Table 5). Although each of the three PVY strains was initially inoculated into $33.3 \%$ of the plants, by 5 weeks after inoculation, the proportions of PVY strains significantly changed for at least two cultivars (Umatilla Russet and Ranger Russet) (Table 5), with Alturas exhibiting a similar trend. At the end of the 5-week experiment, the proportions among all PVY-positive plants in the screenhouse were $22 \% \mathrm{PVY}^{\mathrm{O}}$ $40 \% \mathrm{PVY}^{\mathrm{N}-\mathrm{Wi}}$, and $38 \% \mathrm{PVY}^{\mathrm{NTN}}$ (Table 5).

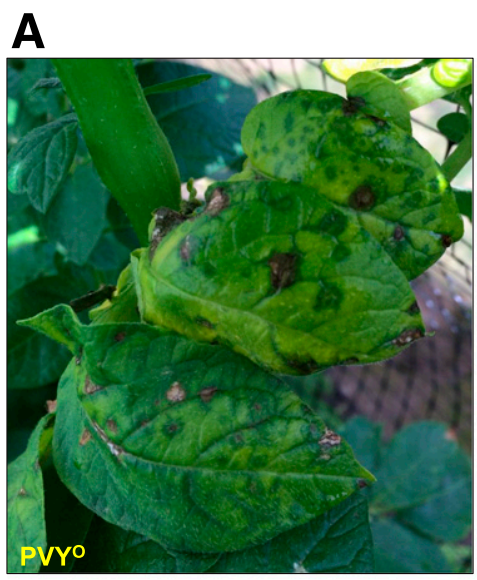

Umatilla Russet
B

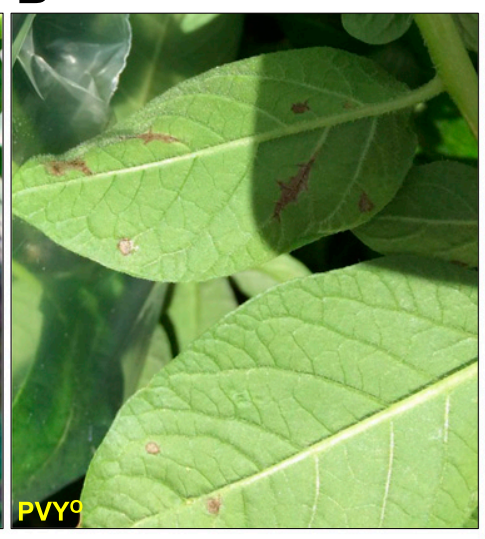

Umatilla Russet

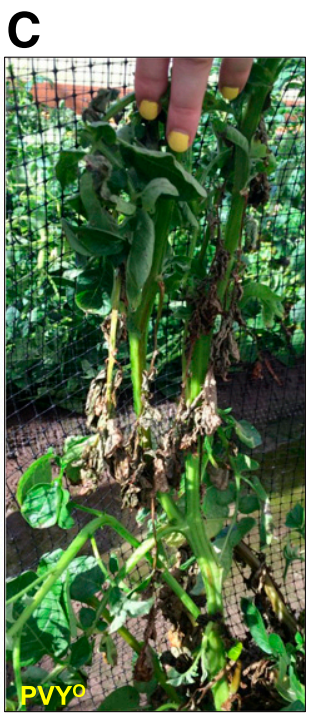

Ranger Russet

Fig. 2. Symptoms observed in the screenhouse experiment. A, Symptoms of green, water-soaking rings and necrotic lesions; and B, vein necrosis induced by Potato virus $Y$ (PVY) isolate $\mathrm{Tb} 60\left(\mathrm{PVY}^{\mathrm{O}}\right)$ in Umatilla Russet as observed at 5 weeks postinoculation (wpi). B, Severe systemic leaf-drop and necrotic stem streaks induced by $\mathrm{PVY}$ isolate Tb60 (PVY ${ }^{\mathrm{C}}$ ) in Ranger Russet at 5 wpi. All plants were tested at 5 wpi by triple-antibody sandwich enzyme-linked immunosorbent assay and reverse-transcription polymerase chain reaction to confirm systemic infection with the isolate or strain indicated.

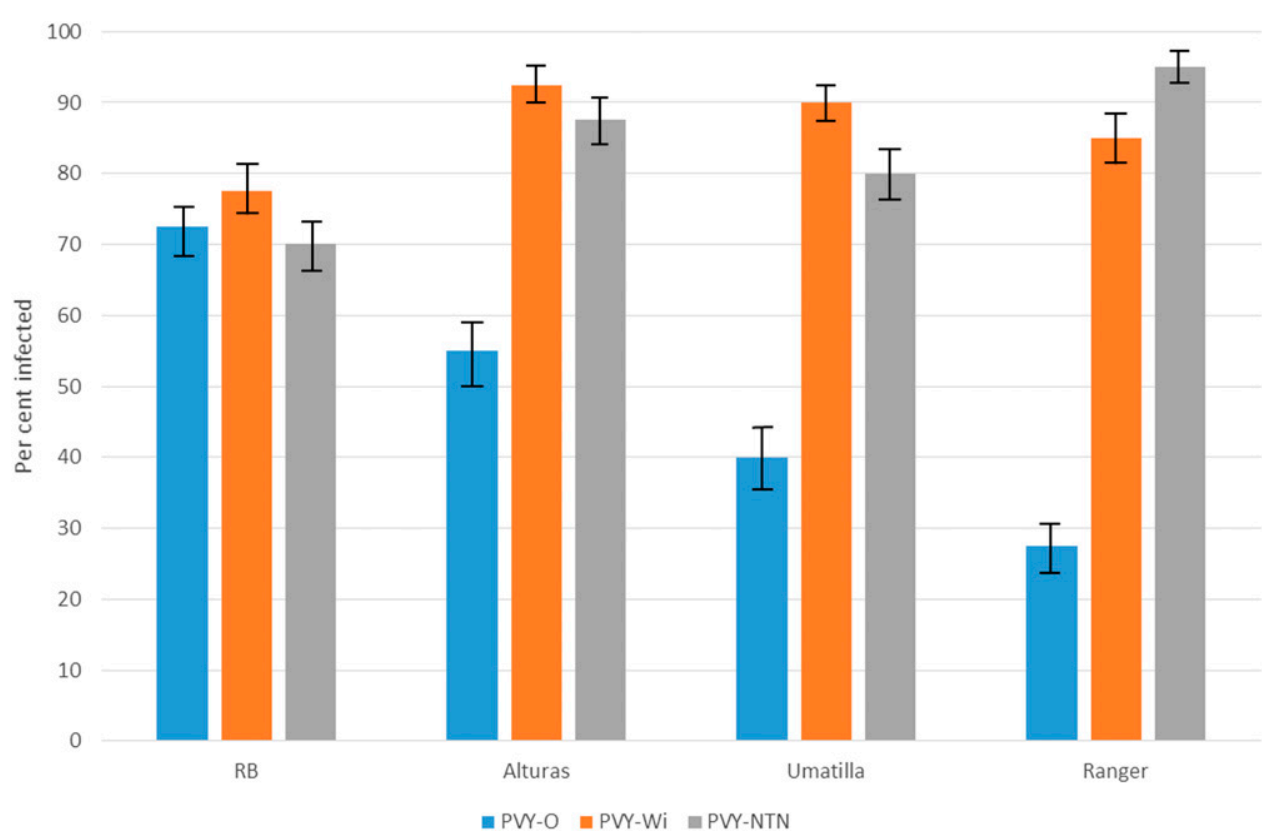

Fig. 3. Infection incidences in the screenhouse experiment determined by triple-antibody sandwich enzyme-linked immunosorbent assay (TAS-ELISA) and reverse-transcription polymerase chain reaction (RT-PCR) 5 weeks postinoculation. Forty individual plants per cultivar-strain combination were inoculated with isolates Tb60 (PVY ${ }^{\mathrm{O}}$ ), N1 (PVY ${ }^{\mathrm{N}-\mathrm{Wi}_{i}}$ ), and HR1 (PVYNTN) in this experiment. The X-axis represents the proportion of the 40 plants found infected with the corresponding PVY strain for each of the four cultivars tested: Russet Burbank (RB), Alturas, Umatilla Russet, and Ranger Russet; vertical bars represent standard error. Each sample was tested for systemic infection using TAS-ELISA, and each positive sample was typed to strain by RT-PCR. 
Resistance in Umatilla Russet against PVY $^{\mathbf{O}}$ is expressed as HR. To further study the response of Umatilla Russet to four different strains of PVY $\left(\mathrm{PVY}^{\mathrm{O}}, \mathrm{PVY}^{\mathrm{N}}, \mathrm{PVY}^{\mathrm{NTN}}\right.$, and PVY $\left.{ }^{\mathrm{N}-\mathrm{Wi}}\right)$, a growth-room experiment was conducted under controlled temperature and lighting conditions and side by side with control cultivars Maris Bard, Desiree, and CalWhite. Both PVYO and PVY ${ }^{\mathrm{NTN}}$ induced a typical HR response (Fig. 4), similar to previously described, in Maris Bard following mechanical inoculation (Rowley et al. 2015). The HR started as necrotic rings developing into local lesions on inoculated leaves at about 7 days postinoculation (dpi). Within 10 to $14 \mathrm{dpi}$, inoculated leaves were fully necrotized. By $21 \mathrm{dpi}$, systemic necrosis and leaf drop were observed, as well as severe mosaic and crinkling of the top, young leaves. Another control, Desiree, produced a very similar HR upon infection with $\mathrm{PVY}^{\mathrm{O}}$, whereas PVY ${ }^{\text {NTN }}$ induced mild systemic mosaic on upper noninoculated leaves 14 to $21 \mathrm{dpi}$. PVY $\mathrm{N}^{\mathrm{N}}$ and $\mathrm{PVY}^{\mathrm{N}-\mathrm{Wi}}$ infection resulted in mild to very mild systemic mosaic with no local lesions observed on the inoculated leaves in either Desiree or Maris Bard. Slight crinkling was visible in upper noninoculated leaves in Maris Bard infected with PVYN and PVY ${ }^{\mathrm{N}-W i}$ (Table 6). Systemic infections of all four isolates representing four strains of PVY were easily confirmed 21 to 28 dpi using ELISA (Fig. 5) and RT-PCR (not shown). However, not all of the Desiree and Maris Bard plants inoculated with Tb60 $\left(\mathrm{PVY}^{\mathrm{O}}\right)$ and not all of the Maris Bard plants inoculated with L26 (PVY ${ }^{\mathrm{NTN}}$ ) established systemic infection (Fig. 5) due to the presence of the $N y_{t b r}$ gene (Desiree) or $N y_{t b r}$ and $N z_{t b r}$ genes (Maris Bard)
(Chikh-Ali et al. 2014; Cockerham 1970; Jones 1990; Singh et al. 2008).

$\mathrm{PVY}^{\mathrm{N}-\mathrm{Wi}}$ and PVY ${ }^{\mathrm{NTN}}$ induced very mild mosaic in systemically infected, noninoculated upper leaves of CalWhite, clearly visible by about 14 to $21 \mathrm{dpi}$, but no other local or systemic symptoms (Table 6). $\mathrm{PVY}^{\mathrm{N}}$ and $\mathrm{PVY}^{\mathrm{O}}$ induced no local or systemic symptoms in CalWhite (Table 6), although virus was easily detected 18 to $21 \mathrm{dpi}$ by ELISA (Fig. 5) and RT-PCR (not shown). Lack of resistance to any of the four PVY strains tested combined with the lack of symptoms exhibited by CalWhite demonstrated that this cultivar is susceptible to these three strains.

$\mathrm{PVY}^{\mathrm{O}}$ induced a distinct local and systemic HR reaction in Umatilla Russet (Fig. 4; Table 6). This included formation of local lesions that later expanded and led to completely necrotized inoculated leaves by 12 to $14 \mathrm{dpi}$. This local HR was followed by a clear systemic HR, which displayed a typical leaf-drop syndrome. Some of the Umatilla Russet plants inoculated with Tb60 (PVY ${ }^{\mathrm{O}}$ ) failed to establish systemic infection, suggesting possible presence of the $N y_{t b r}$ gene conferring strain-specific HR against $\mathrm{PVY}^{\mathrm{O}}$. This was not due to the loss of infectivity of the $\left.\mathrm{Tb} 60(\mathrm{PVY})^{\mathrm{O}}\right)$ inoculum; the infectivity of the same inoculum was confirmed in CalWhite in the same experiment (Fig. 5). PVY ${ }^{\mathrm{N}-\mathrm{Wi}}$ and $\mathrm{PVY}^{\mathrm{NTN}}$ induced mosaic and crinkling in Umatilla Russet (Fig. 4) and led to visible stunting of the infected plants. $\mathrm{PVY} \mathrm{N}^{\mathrm{N}-\mathrm{Wi}}$ induced characteristic chlorotic spots in upper, noninoculated leaves of Umatilla Russet (Fig. 4). In the case of PVY ${ }^{\mathrm{NTN}}$, typical local HR was visible at $14 \mathrm{dpi}$ (Fig. 4A) but only mild

Table 5. Infection incidences in four potato cultivars in the screenhouse after mechanical inoculation with three different strains of Potato virus $Y$ (PVY) ${ }^{\text {a }}$

\begin{tabular}{|c|c|c|c|c|c|c|c|c|c|c|c|c|c|c|c|}
\hline \multirow[b]{2}{*}{ Strain } & \multicolumn{3}{|c|}{ Russet Burbank } & \multicolumn{3}{|c|}{ Alturas } & \multicolumn{3}{|c|}{ Umatilla Russet } & \multicolumn{3}{|c|}{ Ranger Russet } & \multicolumn{3}{|c|}{ All combined } \\
\hline & $\operatorname{Exp}$ & Obs & Tot $(\%)$ & $\operatorname{Exp}$ & Obs & Tot $(\%)$ & $\operatorname{Exp}$ & Obs & Tot $(\%)$ & Exp & Obs & Tot $(\%)$ & $\operatorname{Exp}$ & Obs & Tot $(\%)$ \\
\hline $\mathrm{O}$ & 40 & 29 & 3.0( & 40 & 22 & 23.4 & 40 & 16 & 1 & 40 & 11 & 13.3 & 160 & 78 & 22.3 \\
\hline $\mathrm{N}-\mathrm{Wi}$ & 40 & 31 & $35.2( \pm 10.0)$ & 40 & 37 & $39.4( \pm 9.9)$ & 40 & 36 & $42.9( \pm 10.6)$ & 40 & 34 & $41.0( \pm 10.5)$ & 160 & 138 & $39.5( \pm 5.3)$ \\
\hline NTN & 40 & 28 & $31.8( \pm 9.7)$ & 40 & 35 & $37.2( \pm 9.8)$ & 40 & 32 & $38.1( \pm 10.4)$ & 40 & 38 & $45.8( \pm 10.7)$ & 160 & 133 & $38.1( \pm 5.2)$ \\
\hline Total & 120 & 88 & $\ldots$ & 120 & 94 & $\ldots$ & 120 & 84 & $\ldots$ & 120 & 83 & $\ldots$ & 480 & 349 & $\ldots$ \\
\hline
\end{tabular}

a Forty potato plants per PVY strain were inoculated in a screenhouse with isolates Tb60 (PVYO), N1 (PVYN-Wi), and HR1 (PVY $\left.{ }^{\mathrm{NTN}}\right)$ at the same time, in a complete randomized block design. All plants were tested for systemic infection 5 weeks later using triple-antibody sandwich enzyme-linked immunosorbent assay and typed to strain using immunocapture reverse-transcription polymerase chain reaction. Exp = expected number of infected plants, if the incidence is assumed at $100 \%$ and Obs $=$ actual, observed number of infected plants. Tot $(\%)=$ percentage of plants of a cultivar infected with this particular strain out of the total number of plants of this cultivar infected with all strains tested. A $\chi^{2}$ test for homogeneity was done for each variety assuming a null hypothesis of equal distribution among viral types, and the $95 \%$ statistical confidence intervals are listed in parentheses.
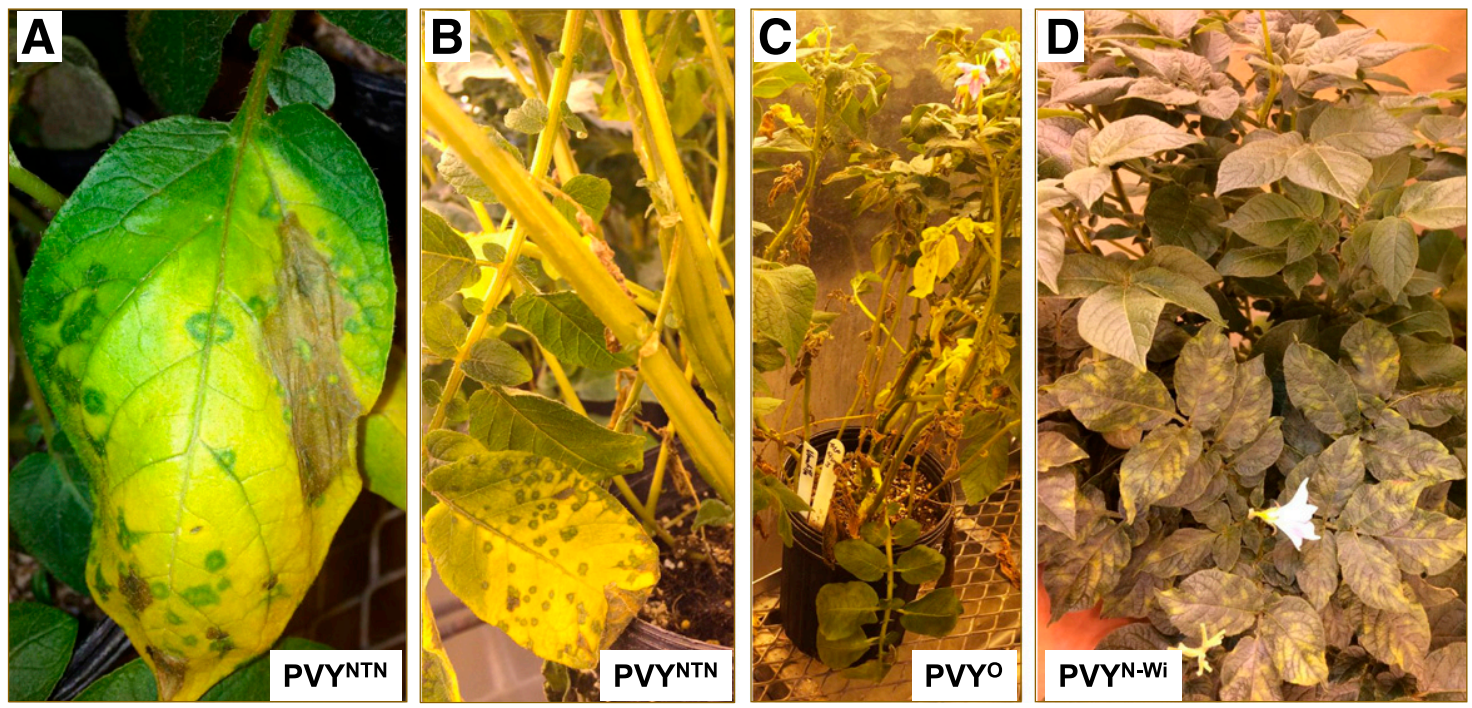

Fig. 4. Symptoms observed in the climate-controlled growth room experiment. A, Inoculated leaf of Umatilla Russet, 2 weeks postinoculation (wpi) with Potato virus $Y$ (PVY) isolate L26 (PVY NTN ): symptoms of green, water-soaking rings, necrotic lesions, and vein necrosis. B, Mild systemic necrosis, leaf-drop, and necrotic stem streaks induced by PVY isolate L26 (PVY ${ }^{\text {NTN })}$ in Umatilla Russet at 7 wpi. C, Severe leaf-drop and necrotic stem streaks induced by PVY isolate Tb60 (PVYO) in Umatilla Russet at 7 wpi. D, Mosaic, mottling, and chlorotic spots induced by PVY isolate N1 (PVY ${ }^{\mathrm{N}-W_{i}}$ ) in upper, noninoculated leaves of Umatilla Russet at 7 wpi. Background: a healthy Umatilla Russet plant. All plants were tested at 4 wpi by triple-antibody sandwich enzyme-linked immunosorbent assay and reverse-transcription polymerase chain reaction to confirm systemic infection with the isolate or strain indicated. 
systemic vein necrosis became visible late in infection, by the end of the experiment, at $50 \mathrm{dpi}$ (Fig. 4B). PVY ${ }^{\mathrm{N}}$ induced only mild to very mild mosaic in Umatilla Russet (Table 6). All plants infected with $\mathrm{PVY}^{\mathrm{NTN}}, \mathrm{PVY}^{\mathrm{N}-\mathrm{Wi}}$, and $\mathrm{PVY}^{\mathrm{N}}$ strains established systemic infection easily confirmed at 21 to 28 dpi by ELISA (Fig. 5) and RT-PCR (not shown).

\section{Discussion}

Recombinant strains of PVY have spread in the past 30 years through the main potato production areas of the world, including strains PVY ${ }^{\text {NTN }}$ and PVY-NE11, which are associated with PTNRD (Baldauf et al. 2006; Blanchard et al. 2008; Chikh-Ali et al. 2016a,b; Galvino-Costa et al. 2012a,b; Gray et al. 2010; Karasev and Gray 2013; Kerlan 2006; Kerlan et al. 1999; Piche et al. 2004; Singh et al. 2008). This spread coincided with the virtual disappearance of other, nonrecombinant strains such as $\mathrm{PVY}^{\mathrm{N}}$ and $\mathrm{PVY}^{\mathrm{O}}$ from

Table 6. Summary of symptoms expressed by different potato cultivars upon mechanical inoculation with four isolates of Potato virus $Y$ (PVY) representing four PVY strains

\begin{tabular}{|c|c|c|c|c|}
\hline \multirow[b]{2}{*}{ Cultivar } & \multicolumn{4}{|c|}{ Isolate or strain of PVYa } \\
\hline & $\begin{array}{c}\mathbf{N 1} \\
\left(\mathbf{P V Y} \mathbf{Y}^{\mathbf{N}-W \mathbf{i}}\right)\end{array}$ & $\begin{array}{c}\text { L26 } \\
\left(\text { PVYNTN }^{\text {NT }}\right)\end{array}$ & $\begin{array}{c}\text { Tb60 } \\
\left(\text { PVYO }^{\circ}\right)\end{array}$ & $\begin{array}{c}\text { Mont } \\
\left(\text { PVY }^{\mathbf{N}}\right)\end{array}$ \\
\hline Maris Bard & $\mathrm{M}, \mathrm{Cr}, \mathrm{St}$ & $\mathrm{M}, \mathrm{Cr}, \mathrm{LL}, \mathrm{SN}$ & $\mathrm{M}, \mathrm{Cr}, \mathrm{LL}, \mathrm{SN}$ & $\mathrm{M}, \mathrm{Cr}$ \\
\hline Desiree & MM & M & $\mathrm{M}, \mathrm{Cr}, \mathrm{LL}, \mathrm{SN}$ & MM \\
\hline CalWhite & MM & MM & NS & NS \\
\hline $\begin{array}{c}\text { Umatilla } \\
\text { Russet }\end{array}$ & $\mathrm{M}, \mathrm{Cr}, \mathrm{St}$ & $\mathrm{MM}, \mathrm{LL}, \mathrm{SN}, \mathrm{St}, \mathrm{LD}$ & $\mathrm{M}, \mathrm{Cr}, \mathrm{LL}, \mathrm{LD}, \mathrm{SN}$ & M \\
\hline
\end{tabular}

a Symptom abbreviations: $\mathrm{M}=$ mosaic, $\mathrm{Cr}=$ crinkling, $\mathrm{St}=$ stunting, $\mathrm{LL}=$ local lesions, $\mathrm{SN}=$ systemic necrosis, $\mathrm{LD}=$ leaf drop, and $\mathrm{MM}=$ mild mosaic. NS indicates no symptoms but the systemic virus infection was confirmed by enzyme-linked immunosorbent assay and reverse-transcription polymerase chain reaction. potato fields in most of the production areas (Blanchard et al. 2008; Karasev and Gray 2013). In the United States, recombinant strains of PVY $\left(\mathrm{PVY}^{\mathrm{N}-\mathrm{Wi}}\right.$ and $\mathrm{PVY} \mathrm{Y}^{\mathrm{NTN}}$ ) were first reported on potato in the early 2000s (Baldauf et al. 2006; Crosslin et al. 2002, 2006; Lorenzen et al. 2006a; Piche et al. 2004) although, in Canada, they were found a few years earlier (McDonald and Kristjansson 1993). Nevertheless, the nonrecombinant strain $\mathrm{PVY}^{\mathrm{O}}$ remained dominant in the United States up to the early 2010s (Baldauf et al. 2006; Gray et al. 2010; Karasev et al. 2010) (Tables 3 and 4).

The data collected in the Pacific Northwest seed lot trials from 2011 to 2015 documented a PVY strain composition shift during this period that was not only dramatic but also very rapid (Tables 3 and 4), resulting in an up to ninefold reduction of the previously dominant strain $\mathrm{PVY}^{\mathrm{O}}$ share to an insignificant minority. At the same time, the relative abundance of the recombinant strains increased greatly from a significant $36 \%$ in 2011 to an overwhelming $93 \% 4$ years later (Table 3). The underlying question that we attempted to answer in this work was: what were the reasons for these dramatic changes in the relative abundance of PVY strains over a period of only 5 years? Between 2011 and 2015, no new strains or variants of PVY were identified in the Othello and Hermiston trials, and the set of strains detected in the samples collected during these 5 years stayed stable (Tables 3 and 4), although improved RT-PCR typing methodology allowed differentiation of up to 14 recombinant genomes known for PVY (Chikh-Ali et al. 2013a). No new aphid species capable of vectoring PVY were reported in the Columbia Basin during this period, making the insect vector an unlikely factor contributing to the observed changes in the relative abundance of stains. Hence, neither changes in the virus nor changes in the vector composition can explain the observed shift in the PVY strain prevalence.

In the past, rapid and significant shifts of the PVY strain profile were hypothesized to occur due to differences in virus-host or virus-vector interactions for recombinant strains of PVY as compared with the nonrecombinant strains (Cockerham 1970; de Bokx

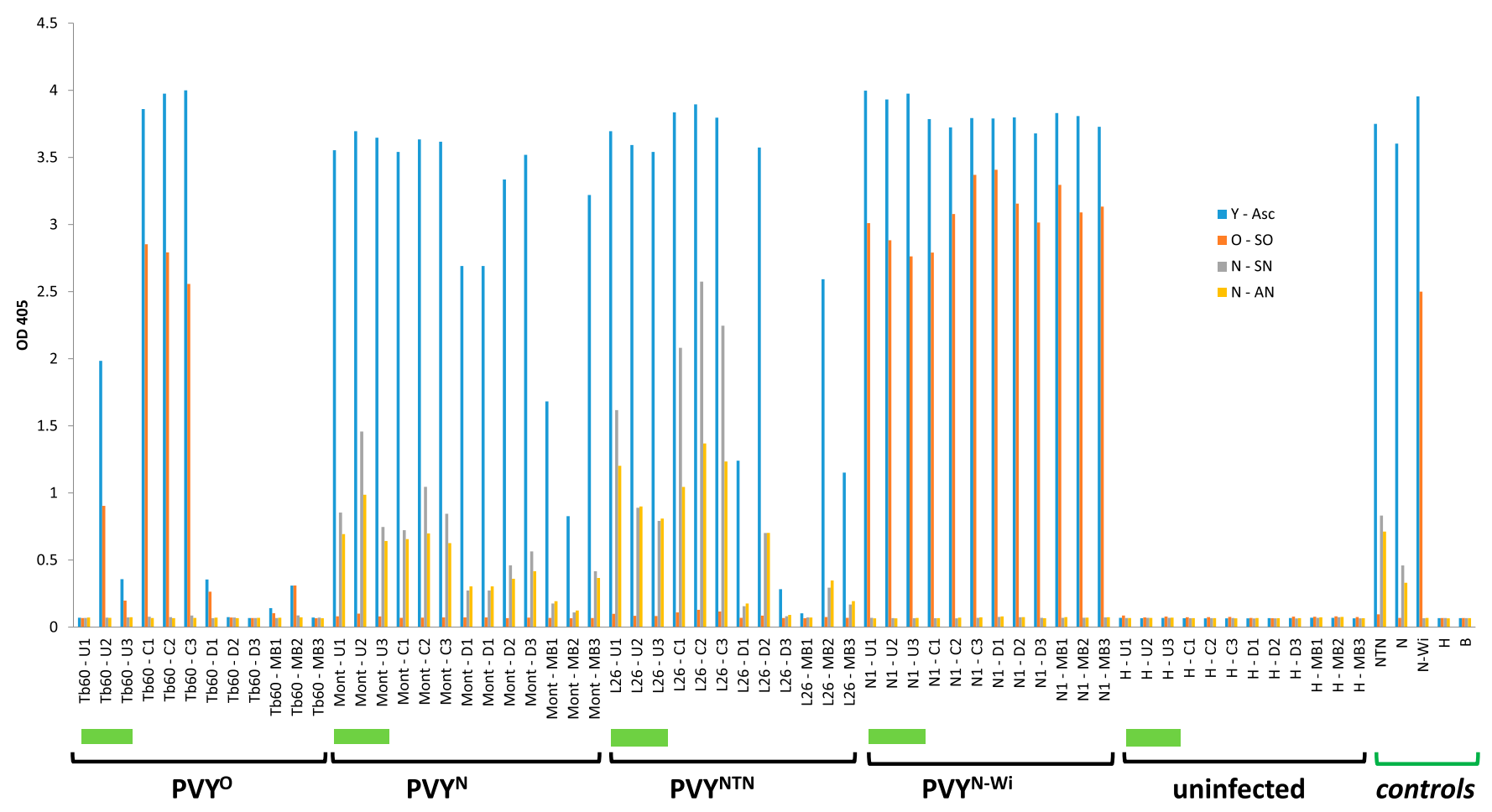

Fig. 5. Example of the triple-antibody sandwich enzyme-linked immunosorbent assay (TAS-ELISA) assessment of Potato virus $Y$ (PVY) infection in four potato cultivars-Umatilla Russet (U), CalWhite (C), Desiree (D), and Maris Bard (MB)-4 weeks postinoculation. Three individual plants per cultivar were infected with each isolate-Tb60 (PVYO), Mont $\left(P V Y^{N}\right)$, L26 (PVY $\left.{ }^{N T N}\right)$, and N1 (PVY ${ }^{\mathrm{N}-W i}$ ) - and three plants were left uninfected. Umatilla Russet plants are labeled with green rectangles. Controls represent tobacco samples infected with corresponding PVY strains. Optical density at $405 \mathrm{~nm}\left(\mathrm{OD}_{405}\right)$ signal reflects the concentration of the respective PVY strain in each individual plant sampled. Bars with different shades represent signals generated with polyclonal (PVY-specific, medium-dark gray) or three different monoclonal antibodies: SASA-O (O-specific, dark gray), SASA-N ( $\mathrm{N}$-specific, medium-light gray), and Agdia-N (1F5, N-specific, light gray). TAS-ELISA plates were read $16 \mathrm{~h}$ after the developing solution was added to the wells, and samples were considered positive if the $\mathrm{OD}_{405}$ signal for the infected plant exceeded the one for an uninfected plant threefold. 
and Huttinga 1981; Jones 1990; Karasev and Gray 2013; Singh et al. 2008). Translocation efficiency of the virus moving from the infected foliage into the tuber was studied for different PVY strains in several potato cultivars (Basky and Almasi 2005; Beemster 1976; Draper et al. 2002). Changes in the efficiency of virus translocation during the development of the plant have long been known to result in the "mature resistance" phenomenon (Sigvald 1985). PVY ${ }^{\mathrm{N}}$ was found to translocate into tubers more efficiently than PVYO (Basky and Almasi 2005; Beemster 1976); however, the studies included multiple other variables, hampering the interpretation of the data. Aphid transmission efficiencies in potato were found to differ about twofold between PVYO and PVY ${ }^{\mathrm{NTN}}$ for at least one colonizing aphid (Carroll et al. 2016), although other tests on a broader range of PVY strains and colonizing and noncolonizing aphids revealed similar transmission efficiencies across most of the strain-species combinations; in particular, no difference was found between $\mathrm{PVY}^{\mathrm{O}}$ and $\mathrm{PVY} \mathrm{Y}^{\mathrm{N}-\mathrm{Wi}}$ transmission (Mello et al. 2011; Verbeek et al. 2010). One of the factors contributing to the transmission efficiencies was found to be the cultivar reaction to the $\mathrm{PVY}^{\mathrm{O}}$ infection. In a cultivar exhibiting $\mathrm{HR}$ against $\mathrm{PVY} \mathrm{Y}^{\mathrm{O}}$, aphid transmission was significantly reduced (Carroll et al. 2016).

The HR reaction conferred by the $N$ genes specific to individual strains of PVY is considered an indication of a host defense response in potato (Chikh-Ali et al. 2014; Cockerham 1970; de Bokx and Huttinga 1981; Jones 1990; Singh et al. 2008). The strain-specific genes $N y_{t b r}$ and $N c_{t b r}$ conferring resistance to $\mathrm{PVY}^{\mathrm{O}}$ and $\mathrm{PVY}^{\mathrm{C}}$ were found to be triggered by genetic determinants of the virus located in the HCPro cistron (Moury et al. 2011; Tian and Valkonen 2013, 2015), which may explain the selection of the PVY recombinants carrying the HC-Pro cistron from the $\mathrm{PVY}^{\mathrm{N}}$ parent unable to trigger these $N$ genes (Glais et al. 2002; Hu et al. 2009a,b; Karasev and Gray 2013; Lorenzen et al. 2006a; Singh et al. 2008). Recently, an additional $N z_{t b r}$ gene was identified in potato conferring resistance to the PVY ${ }^{\text {NTN }}$ recombinant, defining the PVYZ $-N T N$ strain of PVY (Barker et al. 2009; Chikh-Ali et al. 2014; Jones 1990; Kerlan et al. 2011). $N y_{t b r}, N z_{t b r}$, and possibly other strain-specific resistance genes were identified in multiple commercial potato cultivars grown in the United States (Kerlan et al. 2011; Rowley et al. 2015), including Alturas and Ranger Russet, commonly grown in the Columbia Basin (Rowley et al. 2015). The reaction of Umatilla Russet to infection with four strains of PVY and demonstrated HR response to the $\mathrm{PVY}^{\mathrm{O}}$ infection in this cultivar indicated the presence of the $N y_{t b r}$ gene (Figs. 4 and 5; Table 6).

This study documents the unequal impacts that the predominant cultivars grown in the Columbia Basin have on the different recombinant and nonrecombinant PVY strains. These studies provided the first direct evidence that a strain-specific resistance exhibited by the most popular potato varieties grown in this area could result in a significant drop of the $\mathrm{PVY}^{\mathrm{O}}$ strain share of infected plants in a screenhouse experiment, where current-season spread was excluded (Fig. 3). In the screenhouse study, the reduction in the relative abundance of $\mathrm{PVY}{ }^{\mathrm{O}}$ was very rapid, detectable within 5 weeks postinoculation (Fig. 3). This significant, one-third reduction in the $\mathrm{PVY}^{\mathrm{O}}$ strain share observed in the screenhouse experiment after a single round of infection appeared to be the result of strain-specific resistance to $\mathrm{PVY}^{\mathrm{O}}$ infection exhibited by three potato cultivars: Alturas, Umatilla Russet, and, in particular, Ranger Russet (Table 5). Russet Burbank had no strain-specific response against any of the three strains tested (Fig. 3), although this cultivar might have exhibited a weak, nonspecific resistance against all three PVY strains, reducing slightly the overall number of PVY-infected plants (Table 5).

The acreage of the Russet Burbank grown in the states of Washington and Oregon was on a steady, albeit slow decline from 2002 to 2015 , representing now approximately $30 \%$ of all potato grown in Washington and approximately $18 \%$ of all potato grown in Oregon (NASS 2015). If the screenhouse were to approximate the various seed potato production areas supplying potato seed to the Columbia Basin, and representing 25\% shares for each of Russet Burbank, Ranger Russet, Umatilla Russet, and Alturas (Fig. 1), the rapid (within 1 month) PVY strain composition change observed in the screenhouse following inoculations with three strains of PVY (Table 5; Fig. 3) would reasonably mimic the changes observed between individual growing seasons in the field (Tables 3 and 4). However, in the Columbia Basin production area, many more potato cultivars may contribute to the observed strain-specific resistance expression, and other additional factors may contribute to the observed strain composition changes. Indeed, between 2011 and 2015, Russet Burbank made up 18 to $26 \%$ of the seed lots entered into the Washington seed lot trials (Pavek and Holden 2016), which is close to the Russet Burbank share in our screenhouse experiments. Collectively, 26 to $38 \%$ of all seed lots during this period were Alturas, Ranger Russet, and Umatilla Russet; Russet Norkotah contributed between 15 and $17 \%$ of the total; and more than 35 newer or nonmainstream cultivars made up the remaining 22 to $25 \%$ of all seed lots (Pavek and Holden 2016).

\section{Acknowledgments}

We thank W. Price for help with statistical analysis of the data; A. Shrestha, S. Eid, E. Kmieciak, J. Chojnacky, A. Hodnik, D. Vander Pol, B. Thompson, J. Durrin, M. Suliteanu, L. Merlino, and E. Clark for help in sample collection and processing; L. Ewing for providing potato tissue plantlets; and J. Chojnacky for help with the screenhouse plant inoculation and testing. A. Quintero-Ferrer was a recipient of a graduate international fellowship from CONACYT, Federal Government of Mexico. This work was funded, in part, through grants from the United States Department of Agriculture (USDA) National Institute of Food and Agriculture (NIFA) National Research Initiative (2009-35600-05025), USDA-NIFA Specialty Crop Research Initiative (2009-51181-05894 and 2014-51181-22373), USDA Agricultural Research Service (58-5354-7-540, 58-5354-2-345, and 58-1907-8-870), Northwest Potato Research Consortium, Idaho Potato Commission, Washington State Potato Commission, Oregon Potato Commission, and Idaho Agricultural Experiment Station.

\section{Literature Cited}

Anfoka, G., Haj-Ahmad, F., Altaleb, M., Abadi, M., Abubaker, S., Levy, D., Rosner, A., and Czosnek, H. 2014. First report of recombinant Potato virus $Y$ strains infecting potato in Jordan. Plant Dis. 98:1017.

Baldauf, P. M., Gray, S. M., and Perry, K. L. 2006. Biological and serological properties of Potato virus $Y$ isolates in northeastern United States potato. Plant Dis. 90:559-566.

Barker, H., McGeachy, K. D., Toplak, N., Gruden, K., Žel, J., and Browning, I. 2009. Comparison of genome sequence of PVY isolates with biological properties. Am. J. Potato Res. 86:227-238.

Basky, Z., and Almasi, A. 2005. Differences in aphid transmissibility and translocation between PVY ${ }^{\mathrm{N}}$ and PVY ${ }^{\mathrm{O}}$ isolates. J. Pest Sci. 78:67-75.

Beczner, L., Horvath, J., Romhanyi, I., and Forster, H. 1984. Studies on the etiology of tuber necrotic ringspot disease in potato. Potato Res. 27:339-352.

Beemster, A. B. R. 1976. Translocation of the potato viruses $\mathrm{Y}^{\mathrm{N}}$ and $\mathrm{Y}^{\mathrm{O}}$ in some potato varieties. Potato Res. 19:169-172.

Benedict, C., McMoran, D., Inglis, D., and Karasev, A. V. 2015. Tuber symptoms associated with recombinant strains of Potato virus $Y$ in specialty potatoes under northwestern Washington growing conditions. Am. J. Potato Res. 92: 593-602.

Blanchard, A., Rolland, M., Lacroix, C., Kerlan, C., and Jacquot, J. 2008. Potato virus Y: A century of evolution. Curr. Top. Virol. 7:21-32.

Carroll, J. E., Smith, D. M., and Gray, S. M. 2016. Preferential acquisition and inoculation of $\mathrm{PVY}^{\mathrm{NTN}}$ over $\mathrm{PVY}^{\mathrm{O}}$ in potato by the green peach aphid Myzus persicae (Sulzer). J. Gen. Virol. 97:797-802.

Cating, R. A., Funke, C. N., Kaur, N., Hamm, P. B., and Frost, K. E. 2015. A multiplex reverse transcription (RT) high-fidelity PCR protocol for the simultaneous detection of six viruses that cause potato tuber necrosis. Am. J. Potato Res. 92:536-540.

Chikh-Ali, M., Alruwaili, H., Vander Pol, D., and Karasev, A. V. 2016a. Molecular characterization of recombinant strains of Potato virus $Y$ from Saudi Arabia. Plant Dis. 100:292-297.

Chikh-Ali, M., Bosque-Perez, N., Vander Pol, D., Sembel, D., and Karasev, A. V. 2016 b. Occurrence and molecular characterization of recombinant Potato virus $Y^{N T N}\left(\mathrm{PVY}^{\mathrm{NTN}}\right)$ isolates from Sulawesi, Indonesia. Plant Dis. 100:269-275.

Chikh-Ali, M., Gray, S., and Karasev, A. V. 2013a. An improved multiplex IC-RTPCR assay distinguishes nine strains of Potato virus Y. Plant Dis. 97:1370-1374.

Chikh-Ali, M., Karasev, A. V., Furutani, N., Taniguchi, M., Kano, Y., Sato, M., Natsuaki, T., and Maoka, T. 2013b. Occurrence of Potato virus $Y$ strain PVY ${ }^{\text {NTN }}$ in foundation seed potatoes in Japan, and screening for symptoms in Japanese potato cultivars. Plant Pathol. 62:1157-1165.

Chikh-Ali, M., Maoka, T., Natsuaki, K. T., and Natsuaki, T. 2010. The simultaneous differentiation of Potato virus $Y$ strains including the newly described strain PVY ${ }^{\text {NTN-NW }}$ by multiplex PCR assay. J. Virol. Methods 165:15-20.

Chikh-Ali, M., Rowley, J. S., Kuhl, J., Gray, S. M., and Karasev, A. V. 2014. Evidence of a monogenic nature of the $\mathrm{Nz}$ gene conferring resistance against Potato virus $Y$ strain Z (PVYZ) in Potato. Am. J. Potato Res. 91:649-654. 
Cockerham, G. 1970. Genetic studies on resistance to potato viruses X and Y. Heredity 25:309-348.

Crosslin, J. M., Hamm, P. B., Eastwell, K. C., Thornton, R. E., Brown, C. R., Corsini, D., Shiel, P. J., and Berger, P. H. 2002. First report of the necrotic strain of Potato virus $Y\left(\mathrm{PVY}^{\mathrm{N}}\right)$ on potatoes in the northwestern United States. Plant Dis. 86:1177.

Crosslin, J. M., Hamm, P. B., Hane, D. C., Jaeger, J., Brown, C. R., Shiel, P. J., Berger, P. H., and Thornton, R. E. 2006. The occurrence of $\mathrm{PVY}^{\mathrm{O}}, \mathrm{PVY}^{\mathrm{N}}$, and PVY ${ }^{\mathrm{N}: \mathrm{O}}$ strains of Potato virus $Y$ in certified potato seed lot trials in Washington and Oregon. Plant Dis. 90:1102-1105.

de Bokx, J. A., and Huttinga, H. 1981. Potato Virus Y. Descriptions of Plant Viruses, No. 242. Online publication. Commonwealth Mycological Institute/ Association of Applied Biologists, Kew, Surrey, England. www.dpvweb.net/ dpv/showdpv.php?dpvno $=242$

Djilani-Khouadja, F., Glais, L., Tribodet, M., Kerlan, C., and Fakhfakh, H. 2010. Incidence of potato viruses and characterization of Potato virus $Y$ variability in late season planted potato crops in Northern Tunisia. Eur. J. Plant Pathol. 126: 479-488.

Draper, M. D., Pasche, J. S., and Gudmestad, N. C. 2002. Factors influencing PVY development and disease expression in three potato cultivars. Am. J. Potato Res. 79:155-165.

Ellis, P., Stace-Smith, R., Bowler, G., and Mackenzie, D. J. 1996. Production of monoclonal antibodies for detection and identification of strains of Potato virus Y. Can. J. Plant. Pathol. 18:64-70.

Ellis, P., Stace-Smith, R., and deVilliers, G. 1997. Identification and geographic distribution of serotypes of potato virus Y. Plant Dis. 81:481-484.

Galvino-Costa, S. B. F., dos Reis Figueira, A., Rabelo-Filho, F. A. C., Moraes, F. H. R., Nikolaeva, O. V., and Karasev, A. V. 2012a. Molecular typing of Potato virus $Y$ isolates from Brazil reveals a diverse set of recombinant strains. Plant Dis. 96:1451-1458.

Galvino-Costa, S. B. F., Figueira, A., Camargos, V. V., Geraldino, P. S., Hu, X., Nikolaeva, O. V., Kerlan, C., and Karasev, A. V. 2012b. A novel type of Potato virus $Y$ recombinant genome, determined for the genetic strain $\mathrm{PVY}^{\mathrm{E}}$. Plant Pathol. 61:388-398.

Glais, L., Tribodet, M., and Kerlan, C. 2002. Genomic variability in Potato potyvirus $\mathrm{Y}(\mathrm{PVY})$ : Evidence that $\mathrm{PVY}^{\mathrm{N}} \mathrm{W}$ and $\mathrm{PVY}^{\mathrm{NTN}}$ variants are single or multiple recombinants between $\mathrm{PVY}^{\mathrm{O}}$ and $\mathrm{PVY}^{\mathrm{N}}$ isolates. Arch. Virol. 147:363-378.

Gray, S. M., DeBoer, S. H., Lorenzen, J., Karasev, A. V., Whitworth, J., Nolte, P., Singh, R. P., Boucher, A., and Xu, H. 2010. Potato virus $Y$ : A significant and evolving threat to potato crops in the United States and Canada. Plant Dis. 94: 1384-1397.

Hane, D. C., and Hamm, P. B. 1999. Effects of seedborne potato virus Y infection in two potato cultivars expressing mild disease symptoms. Plant Dis. 83:43-45.

Hu, X., Karasev, A. V., Brown, C. J., and Lorenzen, J. H. 2009a. Sequence characteristics of potato virus Y recombinants. J. Gen. Virol. 90:3033-3041.

Hu, X., Meacham, T., Ewing, L., Gray, S. M., and Karasev, A. V. 2009b. A novel recombinant strain of Potato virus $Y$ suggests a new viral genetic determinant of vein necrosis in tobacco. Virus Res. 143:68-76.

Jones, R. A. C. 1990. Strain group specific and virus specific hypersensitive reactions to infection with potyviruses in potato cultivars. Ann. Appl. Biol. 117:93-105.

Jones, R. A. C., and Kehoe, M. A. 2016. A proposal to rationalize within-species plant virus nomenclature: Benefits and implications of inaction. Arch. Virol. 161:2051-2057.

Karasev, A. V., and Gray, S. M. 2013. Continuous and emerging challenges of Potato virus $Y$ in potato. Annu. Rev. Phytopathol. 51:571-586.

Karasev, A. V., Hu, X., Brown, C. J., Kerlan, C., Nikolaeva, O. V., Crosslin, J. M., and Gray, S. M. 2011. Genetic diversity of the ordinary strain of Potato virus $Y$ (PVY) and origin of recombinant PVY strains. Phytopathology 101:778-785.

Karasev, A. V., Meacham, T., Hu, X., Whitworth, J., Gray, S. M., Olsen, N., and Nolte, P. 2008. Identification of Potato virus $Y$ strains associated with tuber damage during a recent virus outbreak in potato in Idaho. Plant Dis. 92:1371.

Karasev, A. V., Nikolaeva, O. V., Hu, X., Sielaff, Z., Whitworth, J., Lorenzen, J. H., and Gray, S. M. 2010. Serological properties of ordinary and necrotic isolates of Potato virus $\mathrm{Y}$ : A case study of $\mathrm{PVY}^{\mathrm{N}}$ misidentification. Am. J. Potato Res. 87:1-9.

Kehoe, M. A., and Jones, R. A. C. 2016. Improving Potato virus $Y$ strain nomenclature: Lessons from comparing isolates obtained over a 73-year period. Plant Pathol. 65:322-333.
Kerlan, C. 2006. Potato virus Y. AAB descriptions of plant viruses, no 414 Online: http://www.dpvweb.net/dpv/showdpv.php?dpvno=414.

Kerlan, C., Nikolaeva, O. V., Hu, X., Meacham, T., Gray, S. M., and Karasev, A. V. 2011. Identification of the molecular make-up of the Potato virus $Y$ strain PVY ${ }^{Z}$ : Genetic typing of PVYZ ${ }^{Z}$ NTN. Phytopathology 101:1052-1060.

Kerlan, C., Tribodet, M., Glais, L., and Guillet, M. 1999. Variability of Potato virus $Y$ in potato crops in France. J. Phytopathol. 147:643-651.

Le Romancer, M., Kerlan, C., and Nedellec, M. 1994. Biological characterization of various geographical isolates of Potato virus $\mathrm{Y}$ inducing superficial necrosis on potato tubers. Plant Pathol. 43:138-144.

Lorenzen, J. H., Meacham, T., Berger, P. H., Shiel, P. J., Crosslin, J. M., Hamm, P. B., and Kopp, H. 2006a. Whole genome characterization of Potato virus $Y$ isolates collected in the western USA and their comparison to isolates from Europe and Canada. Arch. Virol. 151:1055-1074.

Lorenzen, J. H., Nolte, P., Martin, D., Pasche, J. S., and Gudmestad, N. C. 2008 NE-11 represents a new strain variant class of Potato virus Y. Arch. Virol. 153 517-525.

Lorenzen, J. H., Piche, L. M., Gudmestad, N. C., Meacham, T., and Shiel, P. 2006b. A multiplex PCR assay to characterize Potato virus $Y$ isolates and identify strain mixtures. Plant Dis. 90:935-940.

McDonald, J. G., and Kristjansson, G. T. 1993. Properties of strains of Potato virus $\mathrm{Y}^{\mathrm{N}}$ in North America. Plant Dis. 77:87-89.

Mello, A. F. S., Olarte, R. A., Gray, S. M., and Perry, K. L. 2011. Transmission efficiency of Potato virus Y strains PVYO and PVYN-Wi by five aphid species. Plant Dis. 95:1279-1283.

Moury, B., Caromel, B., Johansen, E., Simon, V., Chauvin, L., Jacquot, E., Kerlan, C., and Lefebvre, V. 2011. The helper component proteinase cistron of Potato virus $\mathrm{Y}$ induces hypersensitivity and resistance in potato genotypes carrying dominant resistance genes on chromosome IV. Mol. Plant-Microbe Interact. 24:787-797.

NASS. 2015. North American Potatoes. Online publication. National Agricultura Statistics Service, United States Department of Agriculture. https://www.nass usda.gov/Publications/Todays_Reports/reports/uscapo15.pdf

Nikolaeva, O. V., Roop, D., Galvino-Costa, S. F. B., Figueira, A. R., Gray, S. M. and Karasev, A. V. 2012. Epitope mapping for monoclonal antibodies recognizing tuber necrotic strains of Potato virus Y. Am. J. Potato Res. 89: 121-128.

Nolte, P., Whitworth, J. L., Thomton, M. K, and McIntosh, C. S. 2004. Effect of seedborne Potato virus $Y$ on performance of Russet Burbank, Russet Norkotah and Shepody potato. Plant Dis. 88:248-252.

Pavek, M. J., and Holden, Z. J. 2016. Washington commercial potato seed lot and demonstration trials. Potato Progress 16(6): http://library.nwpotatoresearch.com/ library/document/1382/view

Piche, L. M., Singh, R. P., Nie, X., and Gudmestad, N. C. 2004. Diversity among Potato virus $\mathrm{Y}$ isolates obtained from potatoes grown in the United States. Phytopathology 94:1368-1375.

Rowley, J. S., Gray, S. M., and Karasev, A. V. 2015. Screening potato cultivars for new sources of resistance to Potato virus Y. Am. J. Potato Res. 92:38-48.

Schubert, J., Fomitcheva, V., and Sztangret-Wisniewski, J. 2007. Differentiation of Potato virus $Y$ using improved sets of diagnostic PCR-primers. J. Virol Methods 140:66-74.

Schubert, J., Thieme, T., Thieme, R., Ha, C. V., and Hoang, G. T. 2015. Molecular and biological characterization of Potato virus Y isolates from Vietnam. J. Phytopathol. 163:620-631.

Sigvald, R. 1985. Mature-plant resistance of potato plants against potato-virus Yo (PVYo). Potato Res. 28:135-143.

Singh, R. P., Valkonen, J. P. T., Gray, S. M., Boonham, N., Jones, R. A. C., Kerlan, C. and Schubert, J. 2008. Discussion Paper: The naming of Potato virus $Y$ strains infecting potato. Arch. Virol. 153:1-13.

Tian, Y.-P., and Valkonen, J. P. T. 2013. Genetic determinants of Potato virus $Y$ required to overcome or trigger hypersensitive resistance to PVY strain group O controlled by the gene $N y$ in potato. Mol. Plant-Microbe Interact. 26:297-305.

Tian, Y.-P., and Valkonen, J. P. T. 2015. Recombination of strain O segments to HCpro-encoding sequence of strain $\mathrm{N}$ of Potato virus $Y$ modulates necrosis induced in tobacco and in potatoes carrying resistance genes $N y$ or $N c$. Mol. Plant Pathol. 16:735-747.

Verbeek, M., Piron, P. G. M., Dullemans, A. M., Cuperus, C., and van der Vlugt, R. A. A. 2010. Determination of aphid transmission efficiencies for N, NTN and Wilga strains of Potato virus Y. Ann. Appl. Biol. 156:39-49. 